\title{
Correlation between Visible Teaching and Inquiry - Based Learning
}

\author{
Mihail Calalb \\ Tiraspol State University, Chișinău, Republic of Moldova
}

\begin{abstract}
This work examines modern constructivist teaching approaches with strong feedback component. The author shows that a bidirectional teacher - student communication is a mandatory part of any modern teaching methodology. This fact corresponds to the theory of Visible Teaching and Learning (VTL). The article describes shortly the concept of Inquiry Based Education (IBSE) and demonstrates the existing strong correlation between VTL and IBSE. The research analyses the impact factors on learning and academic achievement of series of constructivist teaching methods. The author underlines the role of two important factors: communication and student's personal learning effort in the formation of sustainable knowledge. In addition, the article presents three mandatory components of any successful teaching approach: inspiring teaching, positive student - teacher relationship and high expectations for students' achievement. Describing in the context of VTL theory the main features of IBSE the author concludes that the shifting should be done from learning by doing to learning by understanding or even learning by being. In the end of the article the author enumerates ten factors related to the correlation between VTL and IBSE.
\end{abstract}

Keywords: visible teaching and learning, inquiry - based education, feedback. 


\title{
World Conference on Teaching and Education
}

\author{
18-20 October, $2019 \quad$ Budapest, Hungary
}

\section{Introduction. Feedback within Visible Teaching Strategies}

The problem of the impact of teaching strategies used in classroom on students' academic achievement and the measurement of this impact is a permanent constant in the field of interest of educational researchers. The most known work in this sense is Hattie's concept of visible teaching and learning (Hattie, 2009). A short description of most powerful teaching strategies according to Hattie's concept is given in the author's work (Calalb, 2019). From the following six main areas which essentially contribute to learning (1- the home; 2 - the school; 3 - the curricula; 4 - the teacher; 5 - teaching modality and 6 - learning approach) we will examine in this section of the article only series of teaching modalities which contain a strong feedback component. Because the essence of Visible Teaching and Learning (VTL) theory could be stated in one and short sentence: from one side the teacher teaches without knowing what namely each student has assimilated, and from other side the student learns only by guessing the learning objectives set by teacher. Thus, the basic actors of teaching - learning process do not act as a harmonic oscillator. In this way, the higher is correlation degree between teacher and student the higher are learning outcomes. Teacher - student bidirectional interaction in classroom provides this correlation. In other words, when teacher is seeking feedback, but in his/her turn, gives feedback to students, and is able immediately adapt teaching according to the feedback from the students. Live streaming of two strongly correlated channels.

According to the concept of VTL, the most powerful teaching approaches should have at least three following components:

Firstly, it is about the quality of teaching when students are inspired to study the proposed subject in an inquiry - based way, to highly value and deeply understand the school subject. As we shall see in the next section, the definition of quality teaching is congruent with inquiry based education.

Secondly, positive student - teacher relationship, or larger, lucrative classroom climate based on multilateral empathy which ensures class engagement toward high achievements (Rogers et al. 2013).

Thirdly, high expectations of teacher for his/her students. Lower expectations determine lower results. Learning effort should be permanently encouraged. It suits with an important didactical principle of the pedagogy of collaboration: the real learning must be hard. Here we have to underline that learning has two sides: surface learning and deep learning, both mandatory. However, deep learning is that part of the learning, which ensures sustainability of the learning and life-long learning potential of personality.

Thus, the most powerful teaching strategy is a priori assumption of the teacher regarding the skills and abilities of a student or group of students when the teacher has adequate expectations for the achievements of his/her students. The impact factor of this approach is 1,62 , which is four times higher than in the case when an experienced teacher applies for two years the same conventional method (Bennett, 2019). 


\section{World Conference on Teaching and Education}

\section{8-20 October, 2019 Budapest, Hungary}

Also the knowledge of students' response to teacher's intervention has an impact factor WORCTE to 1,29 . The strategies containing classroom discussions, which are a mandatory component of inquiry-based education, may have an impact factor up to 0,82 . In addition, in order to reach high results, the students must be aware of success criteria of their learning, i. e. in which way

their success will be measured. The digitalisation of evaluation is the appropriate solution as it eliminates all subjective factors. Thus, knowledge of success criteria has 0,7.

Another strategy related to healthy bidirectional student - teacher interaction is not labelling students or a priori accreditation of students $-0,61$. In this way, as an inappropriate assumption distorts feedback, the communication in classroom should be a coherent one.

\section{Inquiry-Based Learning Strategies}

The active role of the school students in the formation of their ideas and conceptions about the world is recognized by Inquiry-Based Science Education (IBSE). The main feature of IBSE is that the path of a new scientific idea from hypothesis to practical implementation is repeated in the frame of the lesson. At international level, the interest for IBSE grows permanently because IBSE puts the accent firstly on learning effort rather than on teaching. Thus, the constructivist pedagogy of IBSE goes toward the development of understanding, formation of those competences and attitudes that are necessary for every personality in order to have an active life within knowledge-based society. Namely, IBSE projects developed in the classroom by groups of students are essential in the formation of big scientific ideas that, further, will contribute to the understanding of phenomena in the nature, events in human society, and things in the created world (Harlen, 2010). In this way, the analytical, reflection skills of students are formed within IBSE along with patterns of learning strategies which will be further applied by students after their graduation.

IBSE combines empirically several constructivist pedagogies such as: multiple intelligences, Bloom taxonomy, whole method, etc. Thus, IBSE is a strategy based on the following issues:

- $\quad$ Practical work of students, active learning or learning by doing (LBD) - only the first level of IBSE. We should underline that doing is far from understanding. The students may repeat the manipulations of teacher without deeply understanding the sense of their doing. Thus, practical work of students not necessary has intrinsic cognitive value.

- $\quad$ Learning via several learning paths. They often say: I saw - I forgot / I heard - I remember / I did - I understood. There are five feelings and for a whole learning we have to use all of them. As there isn't a panacea for all diseases, there aren't universal pedagogical tools and approaches. It means that the modern teacher has to know many ways for formation and keeping of cognitive and interrogative skills of his/her students. Through multiple intelligences we obtain more students are actively involved into the knowledge building process. This fact is reflected by the rate of academic achievement of each student because the students may choose their own learning path depending on his/her intellectual profile. We have to underline that the deep scientific understanding of the world (Fata Morgana in education) cannot be transmitted to the students; it is the result of their own intellectual effort.

- $\quad$ There are two main levels within IBSE - type learning process. A) Organization of curriculum around big scientific ideas. The students (organized in groups) come to such a big 


\section{World Conference on Teaching and Education}

\section{8-20 October, 2019 Budapest, Hungary}

idea in the frame of their own research project. These big scientific ideas shift the accellonLTE memorization to understanding. B) Organization of the lessons around new three - four scientific terms - sequential character of the lesson. It leads to the assimilation of scientific terms, formation of active vocabulary of students, by training and accustoming them to use scientific speech. Finally, it forms the lifelong learning skills of the person.

An IBSE - based class has differentiated goals and didactical aims for all students. For example, all students explore why things / phenomena are as they are and formulate their adequate explanations on things / phenomena. The majority of students understands that some scientific ideas may be useful for society and for them personally and there are specific scientific research methods, which could be used not only in science. Some students in classroom will replace their own naïve explanations with scientific concepts and will be willing to advance in their scientific understanding of the world.

IBSE is built on natural curiosity of children. Their activism and ardent willingness in primary school and refractive boredom in middle one were the pushing factors for the appearance of IBSE method. In this way, it is very important to create in classroom an environment, which will fuel children's curiosity and endow them with analytical and research skills. It is about meta-cognitive facilitation during the class. Investigation is both a state of mind and a habit that has to be learnt.

The collaboration between students is another crucial aspect of IBSE. The understanding of investigated phenomena or events is built through the conversation among students, which may be developed at class or group level, in the frame of the class or exceeding the time boundaries of the lesson. Via this collaborative conversation the students come to the understanding of new scientific terms, assimilate adequate scientific vocabulary, form for them cognitive values becoming in such a way aware of the essence of scientific research method. The understanding of phenomena and events through ideas sharing is the core and essence of IBSE. Here we have to recall the idea of peer instruction, which was developed in '70s of XX century in URSS by Shatalov V. F. and in XXI century by Eric Mazur from Harvard University, USA (Crouch et al., 2007).

Shortly IBSE is about a higher involvement degree of students meaning that the knowledge resulted from the own research of students are much more relevant and meaningful rather than those delivered by teacher in the form of rigid and undeniable truths. Such an involvement may be reached through enhanced student - student collaboration, as the work within joint projects amplifies the assimilation of knowledge and student - teacher collaboration which forms those sustainable research skills or, simply, lifelong learning skills. In such a way, IBSE is equivalent to collaborative learning which enhances the academic achievement because students link learning act with thinking and understanding.

There are many researches describing the principles of inquiry - based education and a relatively comprehensive work in this sense is an article of the author (Calalb, 2017). Now we will reveal only the main features of IBSE from VTL point of view.

As we already have been stated, IBSE is a constructivist didactic approach recognizing the active role of the students in the formation of their understanding of nature and social world. Being applied permanently in classroom, IBSE forms lifelong learning (LLL) skills, which is 


\section{World Conference on Teaching and Education}

\section{8-20 October, 2019 Budapest, Hungary}

much more important than surface knowledge. In this context, two distinctive factors WORLDCTE underlined: a) deep knowledge obtained due to the own learning effort of student; b) learning skills formed within research projects in the frame of group work. Successful group work means proper communication. Three types of communication ensure positive class engagement:

- In the frame of the group which work on a joint project (problem discussion, identification of the goal, distribution of tasks, debating of obtained results).

- At class level, when the results of groups are presented and analysed by the entire class;

- Teacher - student communication with monitoring and guidance purpose during the whole project length from the initial analysis of the situation to the results discussion.

Proper communication is responsible for the formation of active and reach scientific vocabulary of students, while performing of research tasks is the basis for sustainable LLL skills. Thus, structuring teaching - learning process into a series of research projects is the distinctive feature of IBSE (White \& Frederiksen, 1998). As we mentioned early, usually these projects are organized around big scientific ideas. It means that before adopting IBSE approach a teacher should structure subject curricula into a chain of relatively major scientific terms. Further, for each term or notion the teacher identifies a set of scaffolding questions. The adequacy degree of these pushing questions along with further monitoring and guidance of students group work determines the success.

IBSE is about the involvement of students into the process of collective debates and reflections. The transition from the linear paradigm of memorisation of an amount of knowledge to the one of understanding through involvement requires from teachers those qualities already stated in the previous section. Namely, inspiring students, ability to create in class an atmosphere of empathy, and challenging students. The value of knowledge obtained through the personal effort of students is much higher than the one transmitted by teacher. For example, in VTL the impact factor of learning strategies based on students' personal effort is equal to 0.77. In comparison, ludic education has 0.35 , and one on one laptop programs -0.16 . Remember that numbers lower than 0.4 (reference level) should be interpreted as negative impact factors. In this way, VTL gives a clear response to the adepts of mechanistic gamification or digitalisation of education. In this way, the shifting should be from learning by doing to learning by understanding or even learning by being.

\section{Correlation between VTL and IBSE}

In this section, we will analyse several main features of IBSE from VTL point of view and will demonstrate the similarity, to a certain extent, of IBSE and VTL concepts.

First of all, IBSE is a project - based and problem - based learning. Any IBSE project starts with a class discussion about research object and in which way the students will develop this research. In this sense, each successful IBSE project requires a Research Road Map. Detailed planning of research activities carried out both in classroom and outside ensures the success. As they say, any impromptu needs a good preparation. According to VTL Cognitive Task Analysis is ranked at the level of 1.29. A well-known thing by all teachers that the class has to start with setting properly the learning objectives. Understanding and students' ownership of learning outcomes is the basis of success. 


\section{World Conference on Teaching and Education}

\section{8-20 October, 2019 Budapest, Hungary}

Further, the structure of inquiry - based projects is close to "jigsaw method" (Aronso WORLDCTE (in VTL it has an impact factor equal to 1.2, i.e. it increases the academic achievements of students with $120 \%$ ). This high result is possible due to the overlapping of series of strong factors, such as: differentiated learning, personal learning effort, and sequential learning (when new subjects are taught in small portions).

Finally, the prior knowledge of students lays at the base of any new IBSE project. The recurrent use of previously acquired knowledge, which is actually the Latin phrase Repetitio est mater studiorum, deepens the acquired knowledge. Capitalising the knowledge through repetitive use brings sense to learning, anchor the knowledge into student's value system. If this method is permanently used it could achieve an impact factor equal to 0.93. IBSE requires a certain freedom degree for students in their learning. According to VTL theory, the independence of students in their learning by research is highly paid off with an impact factor equal to 0.83 . We have to mention that this independence needs strong interaction and communication within the group of students. If the classroom climate is a healthy one, students learn from each other. In addition, if the teacher succeeds in project guiding and monitoring, a real feedback brings other 0.92 points to the impact factor. In this way, the permanent integrated implementation of following approaches: basis on prior knowledge; self-regulated learning; and classroom discussions increase the academic achievement of students and the sustainability of their deep knowledge.

\section{Conclusions}

1. Six main factors influence the quality of learning (in order of relevance): home, school, curricula, teacher personality, teaching approach, learning approach.

2. The higher is correlation or empathy degree between teacher and student the higher are learning outcomes and feedback in this case should be seen as live streaming of two strongly correlated channels.

3. A modern teaching approach contains at least three following features: inspiring teaching, empathy - based teaching and encouraging teaching.

4. The quality of communication in classroom determines the formation of LLL skills within IBSE projects. There are three types of communication presented in an IBSE class: student - student among the same group, student - student between groups, and teacher student.

5. Proper communication forms reach and active scientific vocabulary of students, while research activity of students forms sustainable scientific knowledge.

6. Adequately selected set of pushing or scaffolding questions ensure the success of any IBSE project.

7. Learning by being paradigm supposes personal learning effort of students, which is crucial both in IBSE and in VTL.

8. The analysis of cognitive tasks when an IBSE project starts ensures students' understanding and their ownership of learning outcomes.

9. Using in the same time several IBSE techniques, such as differentiated learning, mandatory personal learning effort, and sequential learning we may increase the impact factor of IBSE projects (in terms of students' achievement). 


\section{World Conference on Teaching and Education}

\section{8-20 October, 2019 Budapest, Hungary}

10. Repetitive or recurrent use of previous knowledge, self - regulated learning and teacherce on guided classroom discussions increase cumulatively the impact factor on student learning.

\section{Acknowledgment}

This paper is an output of the science project The Study of Application of Inquiry - Based Science Education Methods in Learning by Doing Virtual Environments - EDUSCIENCE supported by Academy of Science of Moldova. 


\section{World Conference on Teaching and Education}

\section{8-20 October, 2019 Budapest, Hungary}

\section{References}

[1] Hattie, J., (2009). Visible learning: A synthesis of over 800 meta-analyses related to achievement, Routledge, London.

[2] Calalb, M., (2019). Cele mai eficiente zece strategii didactice (The Most Efficient Ten Didactical Strategies), Materialele Conferinței Republicane a Cadrelor Didactice, 1-2 martie 2019, vol. 1, p. 320, ISBN - 978-9975-76-271-7.

[3] Rogers, C. R., Harold L., \& Tausch, R., (2013). On Becoming an Effective TeacherPerson-centered Teaching, Psychology, Philosophy, and Dialogues with Carl R. Rogers and Harold Lyon. London: Routledge, ISBN 978-0-415-81698-4.

[4] Bennette, C., (2019). Visible Learning Ranks Teacher Estimate as \#1 Factor in Learning https://www.thoughtco.com/hattie-visible-learning-4156814

[5] Harlen W., (2010). Principles and Big ideas of Science Education. Hatfield, UK: ASE.

[6] Crouch C. H., Watkins J., Fagen A. P., and Mazur E., (2007). Peer Instruction: Engaging Students One-on-One, All At Once, in Research-Based Reform of University Physics, vol. I, Harvard University.

[7] Calalb M., (2017). Pedagogia învăţării prin investigaţie şi impactul ei asupra deprinderilor de cercetare ştiinţifică şi învăţare pe tot parcursul vieții (The Pedagogy of Learning by Research and its Impact on Lifelong Learning and Research Skills), Studia Universitatis Moldaviae, seria Științe ale Educației, nr.5(105), p. 32-39, ISSN 1857 - 2103.

[8] White B. Y., Frederiksen J. R., (1998). Inquiry, Modeling, and Metacognition: Making Science Accessible to All Students, in Cognition and Instruction, Vol. 16, No. 1, pp. 3-118.

[9] Aronson E.,, (2001). Nobody Left to Hate, Henry Holt and Company, 2001, ISBN 0805070990, 9780805070996, https://www.jigsaw.org/\#steps 